\title{
Interethnic peace, security and genocide in Bosnia-Herzegovina
}

\author{
Ümit Hacıŏlu, $\mathrm{PhD}^{\mathrm{a} *}$ \\ ${ }^{a}$ Assistant Professor, Beykent University, \\ Faculty of Economics and Administrative Sciences, İstanbul, Turkey
}

\begin{abstract}
In the case of Bosnian War (1992-1995), International Participation has just maintained interethnic peace with limited success. Peace-keeping strategies implemented without consensus subsequently set up an environment in which ethnic cleansings transformed into genocide in UN "Safe Areas". According to World Bank's reports; following the end of military conflict late 1995, of a pre-war population of 4.4 million, an estimated 250,000 people had lost their lives or were considered missing, 200,000 to 400,000 people had been wounded, and an estimated 2.5 million people, more than half the population, either left the country as refugees or were internally displaced (The World Bank Report, 2004). Despite what has happened during the turmoil, the worst happened in Srebrenica as one of UN Security Zone which was protected by Dutch soldiers. Still it is unknown how many people had lost their lives in Srebrenica. According to Human Right Watch Reports, ethnic cleansing in Bosnia was systematically planned and implemented by Serbian irregulars. In this article, it is aimed to illustrate the negative effects of dissolving interethnic peace in Bosnia. The case of Bosnian interethnic war has been examined from security matter to genocide.
\end{abstract}

Keywords: Security, Interethnic Peace, Genocide, Conflict, Interdependency

\section{(C) 2012 Published by SSBF.}

\section{Introduction}

Following the end of the Cold War, economic and politic conditions in Yugoslavia deteriorated interethnic security and peace among 'neighbors'. Ethnic and religious roots of the conflict during Tito's Yugoslavia were embedding for long time till Tito's death. However, in the case of Bosnian and Kosovo tragedies, ethnic and religious causes of the conflict did stand in the forefront. Apart from historical problems, economic causes of the conflict have not been yet examined in details. Colleagues have been already writing articles referring initially to both ethnic and religious roots of the conflict. Moreover, extensive studies and researches published in journals address causes of the conflict to genocide in terms of ethnicity rather than timing of International Military Intervention. International scholars also paid less attention to the post-conflict peace and security including the ways of sustaining long term security by creating common interest among conflicting parties in the Balkans. During the collapse of interethnic peace in Yugoslavia, the lack of economic interest, imbalanced prosperities of the constituent states within Confederation, problems with common budgeting system, malfunction of fiscal institutions were at the core of rapid economic deterioration. Paul Collier in his article suggests economic causes of a civil war/conflict might stem from greed and grievance. The first stage of interethnic conflict according to him is extreme rebellions and riots (Collier, 1999: 16). Collier in his article

*E-mail address: umithacioglu@beykent.edu.tr

Tel: +902124441997 
insists that the main impetus behind rebellions is based on resource allocation and capturing resources extra-legally. Overnight the more prosperous northern republics of Slovenia and Croatia were pitted against the less wealthy southern states. The northerners resented having to pay for development of the more backward southerners (Baffin, 1996:101)

In the Balkans sustaining long term interethnic security is to be traced to a number of complex factors. Following the end of turmoil in the Balkans, the last decade reveals the importance of sustaining interethnic security among conflicting parties by maintaining common economic interest rather than solitary military measures. On the other hand, importance of deterrence power of military presence should not be neglected in the Balkans. Military measures and strategies are vital parts of keeping peace and security in post- conflict environment. Bosnian and Kosovo tragedies were ended by international solidarity and humanitarian intervention. However, maintaining security in the conflicting areas by belated military strategies was ageing and tiring for victims of the war. Belated arrival of strong military operations, imposing economic and arms embargo provoked genocide (Holbrooke, 1998; Yenigün, Hacıoğlu, 2004:186; Hacıoğlu, 2008:189-210). However, belated Military measures were vital instruments to end tragedies but could not make sure of sustaining long term peace and security as conflicting parties still debating on territorial issues, displaced people, use of economic resources, and judgment of war fugitives. Hence, international community must contribute and facilitate initially peace progress by mediating unresolved issues and maintaining common interest among conflicting parties. Paul Collier in this issue stresses economic policy priorities in post-conflict societies. According to him, in order to sustain long term security in post conflict environment, conflicting parties need to reduce the underlying risks of conflict involving the same policies which are appropriate in conflict prevention, such as diversification and poverty reduction( Collier, 1999: 13) Common interest also composes of both social and economic agendas including sustaining improvement in health, education and culture, righteous judgment of fugitives, compensating war crimes, functionalizing open market principles, encouraging FDIs, mediating territorial disputes and sustaining transparency.

\section{Interethnic Peace, Security and Conflict in Bosnia}

Understanding the concept of security and its theoretical frame is necessary before evaluating the past and future conditions affecting interethnic peace in the Balkans. The traditional security paradigm in international relations is the main element of realist school in which state structure is prior focus point. During the Cold War, main actors- super powers- enhanced security of their countries attaching security of nation to a balance of power condition among other dominant states. Therefore sovereignty of nation-state is attached to military power and sustaining security by military measures covering influence areas at external peripheries. During the post Cold War period, globalization has changed evolution of this theorem. The latest developments in internet and communication technologies crystallized globalization process in which new security paradigm emerged. International terrorism, self-determination and humanitarian intervention were deliberately linked to security questions. As well as emerging new security architecture following the collapse of Soviet Union, internet and communication technologies today specifies globalization process which has already marked significantly (Y1lmaz, 2007: 1)

The concept of Security must be evaluated considering two different dimensions: National Security and Interethnic Security. National Security is vital for a nation state which is clearly unified and one dominant nation is sovereign enhancing minorities such as Turkey, Greece and Germany. (2) Interethnic Security is vital for collective constitutional system in which constituent states compose of multiethnic groups and diversities such as Bosnia and Herzegovina. Globalization in the first dimension might be challenging for national security as Yllmaz advocates (Yllmaz, 2007: 1-15). According to him, Globalization has its influences on security as (Yılmaz, 2007: 3; Yllmaz, 2006: 97-98);

(1) Appearances of International and transnational structures defects the national sovereignty... (2) Global economic integration limits the national control over economy and the central governments, and weakens the state. (3) as economy emerges as the most important engine of national power, international economic actors including IMF, NGOs are the most important factors defining the parameters of development of national economy. (4) Transnational social and religious activities challenge the national security. (5)Global communication and transportation make it difficult to have 
control over nation state boundaries. (6) National Union is under threat of ethnic and religious diversity, and self-determination.

Apart from the negative effects of Globalization process on National Security, the Civil war in Yugoslavia examined the boundaries of sovereignty and the ways of sustaining security. Global communication and effects of independent media groups, NGOs, social pressure groups urged international community to consider seriously what has been happening in Bosnia and Kosovo. Hence, International participation intervened into conflict, kept the peace, maintained and sustained security among conflicting parties by military measures. In the contrary, the prevalence of humanitarian intervention brought new questions on issue of sovereignty of a nation state and sustaining security. Humanitarian intervention is one of the primary international security problems of today (Fixdal and Smith, 1998: 283). Despite the challenging controversies, conditions of post-conflict environment could not be managed by global actors and NGOs. According to Crisis Prevention and Recovery Report, Post- Conflict Economic Recovery requires not only sustained economic growth, but also reducing the risk of conflict recurring. Therefore sustainable growth must be accompanied by employment expansion (UN, 2008: 24). However, official unemployment rate in $\mathrm{BH}$ throughout the past decade was exceeding 40 percent. World Bank Office in Bosnia announced that social expenditure in $\mathrm{BiH}$, one of the highest in Europe as percentage of GDP, reaches only 30 percent of those most in need in $\mathrm{BiH}$, one of the lowest rates in Europe(http:/go.worldbank.org/54PCSU2E90). According to Report it is critical to sustain recovery efforts primarily promoting policies that attract private sector investment as well as the return of skilled workers (UN, 2008: 24).

Recently, in the Balkans interethnic peace sustained by international participation is prone to disappear as security problems are associated with economic development progress of new emerging states at region, new collective presidency and power sharing system, global economic crisis, higher unemployment rates, deficiencies in budgeting system. Moreover, intensive political burdens within power sharing system melt down security policies and escalated ancient hatreds especially following Kosovo's independence in 2008 (Hacioğlu, 2008: 189-195).

\subsection{The Collapse of Interethnic Peace and Security in the Former Yugoslavia}

Interethnic peace and security in the Balkans always became challenging issue as stability maintained by hegemonic powers disappeared during power shifts (Hagen, 1999: 57-64). Scholars pointed out that instability stems from the security gaps traced to changes in power shifts (Malcolm; 1994). ... BiH must surely be the 'powder-keg' of the Balkans. Traditionally, this label can be attributed because the republic sat on the fault-line between the Christian empires of Central Europe and the Ottoman Empire (Griffiths, 1993: 52).

Griffiths in this argument should have attributed Bosnia and Herzegovina as the country of peace and tolerance since 15 th century to 18 th during Ottoman Rule. Only between 16th and 17th centuries, BiH contributed Ottoman State system with more than 9 Vezir-i Azams and countless high rank officers. Following nationalism movements in Europe, ethic groups in the Balkans had revolted weakening the interethnic security within Ottoman State. Habsburgs invaded Bosnia in 1878 and had supremacy until 1908. However, following years Orthodox Russian backed- Serbs revolted against Ottomans and invaded Kosovo during 1912 Balkans War and declared independency after a short time. Hagen and Malcolm stress that during power shifts from Ottomans to Habsburgs and from Habsburgs to the Kingdom of Serbia, countless Croatians, Serbians and Bosnian Muslims were massacred (Hagen 1999:57- 60; Malcolm 1994). These massacres had cultivated the ancient hatreds among Serbs and Croatians significantly. European historians accept at least 500.000 people were killed during Utasha's slaughter (Baffin, 1996: 99)

"From the beginning of the post-1918 nation, violence permeated politics. In 1928 Serb extremists assassinated Stefan Radio, Croatian leader of the powerful Peasant Party, in the parliamentary chamber and bloody riots erupted all over Croatia. The following year the desperate King Alexander declared a royal dictatorship and tried to replace Serbian and Croatian nationalism with patriotic country of 'Yugoslavia'. ... Utasha movement in 1934 pioneered by Ante Pavic backed by Mussolini in Italy and the new Nazi Party in Germany assassinated King Alexander. ... After the German - Italian invasion of Yugoslavia in 1941, Hitler and his Nazi ssociates used he hatreds of the Balkan people to divide then. He offered the Croatians their independence and installed Ante Pavic as puppet ruler. With the Nazi's blessing, Pavic set out to 'purify' his new nation; fifty years later this bestial actively would be called 'ethnic cleansing' (Baffin, 1996: 99)” 
Malcolm also argues that Serbian hatred and atrocity against Bosnian Muslims derives from Islamization of BosnianBogomils and termination of Serb Army during The Kosovo War of 1389 (Malcolm, 1994 ).

\subsubsection{Pre-conflict security Strategy: Coercion Vs. Constitutional Rights}

Who secured best among conflicting groups in short time? How to secure interethnic peace? The answer is clear behind another question! Did you see any interethnic groups in Yugoslavia? Tito was successful liberating Yugoslavia and creating one single identity until his death. The tools which he had used to unify different ethnic groups were initially coercions and finally constitutional privileges given to constituent states.

During WWII, UK and Russian backed Josip Broz Tito with his partisans pioneered liberation movement ending Nazi's Occupation of Yugoslavia. Tito declared himself as Marshal in 1945 with all respect of all ethnic groups. Interethnic peace during Tito's ruling had been once more sustained among conflicting parties but in one identity of Yugoslavians. Meanwhile, religious and ethnic based differences were coerced during Tito's time. Boy's Sunnet tradition of Bosnian Muslims working state departments was forbidden. Sometimes, Muslims were forced to eat pork. Religious practices were also urged to do behind back doors. After a short time, Yugoslavia's foreign policy became friendly with Islamic countries in order to gain from trade petroleum commodities (Malcolm, 1994). Then, Relaxation of forbidden Islamic practices contributed into obedience of Bosnians to Yugoslavia. In fact, the split of Yugoslavia's foreign policies from the orbit of Soviet Union seals Yugoslavia's future much closer to Europe. Tito even broke away from Moscow's domination and in 1953 he introduced a 'third path' between Stalinism and Western imperialism (Baffin, 1996: 99-100)

\subsubsection{Ancient Hatret}

As mentioned before, security during Tito's Yugoslavia was sustained mainly by coercions on historical, ethnic and religious differences. In addition to this, wealthy Slovenia and Croatia were urged to pay more taxes and allocate resources to common economic system of Yugoslavia. Nevertheless, collective leadership and constitutional rights were given to states within Yugoslavia in 1974. Overnight the more prosperous northern republics of Slovenia and Croatia were pitted against the less wealthy southern states. The northerners resented having to pay for development of the more backward southerners (Baffin, 1996:101) Resource allocation and heavy taxation of export commodities sparked the nations seceded. As I attributed to Collier's article in the beginning, the main impetus behind rebellions is based on resource allocation and capturing resources extra-legally. According to Collier, Successful rebel organizations place considerable emphasis upon good public relations with the international community (Collier: 1999:1) Croatia and Slovenia were economically prosperous and had strong economic ties with European countries in terms of trade and tourism.

Dissolving interethnic peace in Yugoslavia was not only stemming from ancient atrocities, but also role of TVs and newspapers, novels in literature, revival of ancient stories, nationalist propaganda led by academicians in Serbia, economic devastation and so on. Rational-choice theorists, motivated by the Yugoslav wars, have focused on ethnic warfare, but they have not always felt obliged to offer a theory of ethnic conflict in general. For them ethnic war is produced by the sense of insecurity that emerges when an actor is unsure of the intentions of another actor and the two are already mutually hostile(Horowitz, 1998). After Tito's death in 1980, mistrust and embedded ancient hatred took place once more in TVs (Peterson, 1996). Old stories and nationalist expressions in Serbian and Croatian literatures (Sells: 1998: 23-43) were intensified following devastation of economy (Ramet, 1996: 44)

Besides the decline in production in 1990 , unemployment rate more than $\% 15$, inflation rate more than $\% 125$, foreign debt more than 20 billion $\$$, budget deficits level approximately 3 billion $\$$, decline in foreign currency levels from 6,5 Billion to 3,6 billion $\$$ devastated the country wide economy( Ramet, 1996: 44-48). Here we should note that before the collapse of Socialist Federal Republic of Yugoslavia, Serbian domination over country's collective presidency and allocation of resources challenged the constituent states of Yugoslavia to secede.

\section{Brutality and Genocide in Bosnian War}

The basics of interethnic peace in the Balkans rely on interethnic security which can be sustained by implementing economic and social measures. Common social and economic interests must be composed of all ethnic groups without 
coercion. Tito's charismatic leadership and fame after World War II gained the respects of fractious groups but not excluded coercive policies among them. As I mentioned before, interethnic security was sustained by initially coercion and finally constitutional rights given to states within Yugoslavia during Tito's time. As expected, after the death of Tito in 1980, effective power mover at an ever more raped rate from the federal centre to regional party leader, and as the economy began to decline, regional leaders started to take an interest in local ethnic problems an in promoting division between the constituent nations (Griffiths, 1993: 41). Origins of civil war are broadly consistent with an economic motivation and with grievance (Collier, 1999:2).

After Slobodan Milosevic became the leading political figure in Serbia and the former Yugoslavia, the high degree of autonomy Kosovo had been granted in 1974 was revoked then security in Kosova and in other parts of Yugoslavia became the real matter for civilians. .. the constitution prompted the development of a sense of real grievance among Serbians that was not addressed effectively until Milosevic rose to power( Griffiths, 1993:41) After a while the province was brought under Belgrade's direct control in March 1989. The move was followed by the mass sackings of Kosovo Albanians from state-run companies and institutions, including the police, schools and Pristina University. Others who were not fired left their jobs in sympathy. The Kosovo Albanian media was suppressed and education in the Albanian language was suspended, to be restored in 1994(www.setimes.com). Based on Slobodan Milosevic's hostile policies, Bosnian Muslims, Kosovo Albanians and other ethnic groups became the victims at streets. Serbian national hatred against Bosnian Muslims and Catholic Croatians caused ethnic distortion and fed disharmony among Serbian, Croatian and Bosnian neighbors. Milosevic's rise to power prompted a further resurgence of nationalist feeling among Serbs and equally nationalist feelings in Slovenia and Croatia (Griffiths, 1993: 41-42). In 1989, Slovenia introduced a new constitution guaranteed the right to secede from Serb dominated Yugoslavia. The constitution caused demonstrations in Serbia. In 1990, Slovene Communist Party abolished itself and the Slovenian National Assembly issued a declaration of sovereignty (Griffiths, 1993: 42). In 1990 Serb minority in the Croat city of Knin also decided to hold a referendum which turned into armed insurrection. Yugoslav turmoil and security of ethnic groups became devastated. Armed conflict could not be prevented as European Community considered the crisis as Yugoslavia's internal crisis.

Apart from EC's uninterested approach to Yugoslavia's internal security manner, the Community surprisingly paid more attention to Slovenian and Croatian declaration of independence rather than BiH. Bosnia and Herzegovina's population is a mix of Bosniks ( 43 per cent), Croatians( 17 per cent) and Serbians( 32 per cent). By the elections of 1990 in Bosnia, Bosniaks had the largest share of seats in the National Assembly while Croatians and Serbs were confronting each other on ethnic issues. Meanwhile, Bosnian side within federation determined her policy on democratic tradition declaring self- disarmament and announced that there ware no plans to secede. However, Serbian ethnic group of Bosnia had been heavily armed. Self- Disarmament of Bosnians changed the balance power within former Yugoslavia while Cetnics- Serbian irregulars- were being supported by JNA (Yugoslavian Army).

Once more, security within state was prone to interwar as escalating demands of minorities over Bosnian governance. The Muslims had no desire to live in a 'Greater Serbia', a fate that seemed inevitable as Serbia secured control of territory across Croatia in autumn 1991; likewise they had no real wish to be subject to the political pressure that would come from an alliance with Croatia, which had as much interest tin taking a slice of Bosnia and Herzegovina as it did of making strategic deals against Serbia (Griffiths, 1993: 53). After declaring independency, Bosnia and Herzegovina entered into turmoil and chaos. Serbia backed Serb Cetniks( Irregular Serbian paramilitary group) systematically stepped into rapes and ethnic cleansings between Bosnian terrains. According to International Court of Justice's decision in April, 2007, the events in Bosnia were defined as genocide. However, Serbia's acquittal was decided by Court, although Serbia provided ammunitions for Cetniks (Hacioğlu, 2008:205).

According to World Bank's reports; following the end of military conflict late 1995, of a pre-war population of 4.4 million, an estimated 250,000 people had lost their lives or were considered missing, 200,000 to 400,000 people had been wounded, and an estimated 2.5 million people, more than half the population, either left the country as refugees or were internally displaced (The World Bank Report, 2004). Despite what has happened during the turmoil, the worst happened in Srebrenica as one of UN Security Zone which was protected by Dutch soldiers. Still it is unknown how many people had lost their lives in Srebrenica. According to Human Right Watch Reports, ethnic cleansing in Bosnia was systematically planned and implemented by Serbian irregulars (A Helsinki Watch Report: Human Rights Watch, 1992; 1993). What has happened at the core of Central Europe is never to be forgotten. The things happened in 
Sava River, Brcko, Zepze, Tuzla, Zenica, Bihac and Sarajevo and especially in Srebrenica stain peace and international justice (Hacıoğlu, 2009: 2006). Thousands of Muslims in Srebrenica were massacred without any mercy in warehouses, soccer fields and terrains ( Holbrooke, 1998:69)

\section{Peace-Keeping and Stabilization in the Bosnian War}

In the case of Yugoslavia's break-up, security matter turned into genocide within Bosnia and Kosovo territories. Problems associated with timing and scale of UNSEC's peacekeeping measures in Bosnia, in fact, encouraged Serbian authorities to pursue aggression. Aggressions in Bosnia especially within safety areas turned into genocide . Hence, belated peacekeeping measures were not effective as peacekeeping forces could not have been keeping themselves secured. Apart from the failure of UN's peacekeeping strategy, NATO military forces led by US succeeded to intervene into conflict demonstrating desire and ambitious. Second and third phase of intervention was peace stabilization and implementation. However, Dayton Peace Accord (DPA) is not successful to sustain long term peace. Still politic and economic contradictions between constituent states RS and Federation of Bosnia and Herzegovina are devastating the functionality of Bosnian State. The Accord, in this way, is a premature agreement for stabilizing interethnic peace and security.

If the Balkans is to be considered the 'powder-keg' of Europe, then Bosnia and Herzegovina (BiH) must surely be the 'powder keg' of the Balkans (Griffiths, 1993:52). Despite the turmoil intensified at the core of European security and influence zone, European Community was not desirous to manage the conflict with full operation. Moreover, EC was not also capable to put an end to one-side Serbian dominated interwar with military intervention. While both the United States and the European Union initially viewed the Balkan wars as a European problem, the Europeans chose not to take a strong stand, restricting themselves to dispatching U.N. "Peacekeepers" to a country where there was no peace to keep, and withholding from them the means and the authority to stop the fighting (Holbrooke, 1998: xv). Meanwhile, debates on which military and economic measures should be taken by International Community among UN, NATO, EC members were endless and sparked Serbian authorities to pursue the aggression. The principal performers in the tragedy were not even considering peace and UN, NATO and US intelligence about their intentions seemed strangely limited (Baffin 1996:105)

Why does the world notice and intervene in crisis while paying less attention to others? Answer is not simple. Countless facts behind belated military intervention were available. Understanding timing of Humanitarian Intervention begins enumerating some factors as followings(i)Both the United States and members of UNSEC initially viewed the Balkan wars as a European problem, (ii) Dissidences among EC members,(iii), Lack of institutions within EU to support preventive diplomacy,(iv) The contradictions of the UNSEC members, (iv) Lack of EU's economic interest with Bosnia, (v) Lack of EU's capacity to use enforcement operations (vi) Attitude of crisis as being part of Yugoslavia's internal problem, (vii) Ongoing and ageing debates on the nature of Humanitarian Intervention, (viii) UNSEC's approach traced to possible success of economic sanctions and arms ambargo. (ix) Complexity of the Issue as Multiethnic conflict, (x) Lack of knowledge for background, context and dynamics of the conflict, (xi)EU's Attitude of diplomatic deterrence is enough to sustain peace without use of armies, (xii)EU's Attitude of Third party mediation could prevent aggression, (xiii) The break-up of Yugoslavia and violence were neither sudden nor unpredictable. EU and UNSEC were not fully prepared for Intervention.

\subsection{Is only Peacekeeping Efforts by military measures in conflicting areas enough to secure and maintain peace?}

The answer is not simple while other domestic and external factors affecting the nature of conflict. In some cases, economic sanctions are useful and peaceful tools of deterrence diplomacy rather than rapid military intervention strategies. However, the conflict in Bosnia was deeper and brutal as well as economic sanctions were on way to warring parties. Because of the scale and scope of the conflict in Bosnia, humanitarian intervention must have been faster to keep and maintain peace. It could not have been successfully implemented because of timing and lack of willingness of International Community. ... it is the question of will, or lack of it, which has been a central feature of criticisms of United Nations's UN Action in Bosnia( Gow 1997; Fixdal and Smith, 1998: 284) Hundreds and thousands of civilians lost their lives. Thousands of them were wounded. Countless children who lost their families were mentally affected. The devastation and human suffering of the war were on a scale not seen in Europe since World War II( The World Bank: BiH, 2004). As Fixdal and Smith criticize willingness of UN's Action in war, it can be extended to the International Community's role. 
Old Security Strategy preventing deadly conflicts consists of preventive diplomacy, the neutralization, peaceful settlement of conflicts. Unilateral interventions by major powers have declined, through not entirely disappeared, and they have been replaced by the UN and increasingly, NATO interventions (Vayrynen, 1990:2)

\subsection{Peacekeeping and Security in Interethnic Conflict}

At the beginning of conflict in Bosnia, international community were far from agreement and did not know why it was necessary to intervene into conflict as it was seen as an internal matter of Yugoslavia. However, expectations of international societies became higher as turmoil escalated and deepened. Particularly, timing of International Intervention was criticized comparing the effective collective response to the Gulf crisis.

With the collapse of preventive diplomacy including economic and arms embargo, it was not inevitable to utilize military instruments for the purposes of deterrence and territorial control. Interethnic security and peace which devastated in Bosnia, was then object to peace restoration strategies including peace-making and keeping. In the case of of the UN deployment in Bosnia, the use of force was authorized to ensure the delivery of aid and to deter attacks against "safe areas" (Turkovic, 1996: 20). As Serbian aggression could not be controlled, UN's deployment in Bosnia was not enough to implement the task of securing "safe areas". According to Chapter VII (SCR 770) resolution which was adopted by UN Security Council, "member states were responsible to act nationally or through regional organizations to take all measures necessary to facilitate, in coordination with the UN, the delivery of humanitarian aid, following its unprecedented step of renewing UNPROFOR's mandate under Chapter VII to ensure the security of UNPROFOR" and to "ensure its freedom of movement for all its missions (SCR 815)". UNPROFOR was authorized and responsible for peacekeeping and drawing a thin blue line determining the Serb-held areas. UNPROFOR was initially responsible to keep peace and maintain security in UN Safety Zones: these were Bihac, Tuzla, Zepze, Gorazde, Sarajevo and Srebrenica. The task of UNPROFOR was defined in Chapter VII resolution and associated with protecting safe areas (SCR 819-24-36-44). UNPROFOR was also authorized to enforce 'no-fly-zone' (SCR 816).

\subsection{Massacres in Safety Areas}

UNPROFOR had more than 10.000 troops in the beginning. On 12 February 1992 UN Security council Resolution 743 endorsed a proposal to send extra peacekeeping forces deployed. New task was to sustain ceasefire, begin disarming the Serbian militias and to check the withdrawal of the JNA in Sarajevo, Bosnia. However, UNPROFOR was not able to secure its own security as carrying out security tasks for "Safe Areas". UNPROFOR deployed in Sarajevo was only witnessing how civilians were being brutally targeted. (Hacioglu, 2008: Documentary Film). Serb tanks guns and artillery positioned on heights around the city kept up a relentless fire and snipers at closer range picked off pedestrians, car drivers and tram passengers. People were dying as they queued for bread; children were slaughtered as they played in the parks. The Serbs showed no mercy to the residents of Sarajevo. A Seven-year-old boy, Nermin Divocic, was hit in the face by a sniper's bullet in the middle of Sarajevo while holding his mother's hand as they ran past a UN armored personnel carrier. The sniper then shot Nermin's mother in the stomoach so she would not die immediately but would watch her son die first. The most horrific event of the period occurred on 12 February 1994 when a mortal shell burst in Sarajevo's central market, killing 68 people. Seeing the carnage on television, the American and European leaders issued an ultimatum to the Serbs: Stop shelling Sarajevo. Pull back all guns, heavy mortars and tanks 30 kilometers from the capital and put them under UN control (Baffin, 1996: 103). Issuing ultimatum just encouraged the Serbs to pursue aggression as it has not been suggesting ground troops with heavy weapons would have been put into Sarajevo and other parts of Bosnia. Ratko Miladic carried out the biggest genocide, which was not seen in Europe since World War II. The extent of the massacres held in Gorozde, Zepa and especially Srebrenica still cannot be identified. Why the extent of massacres carried out within "safety areas" was larger at scale and scope?

UN Safety area of Srebrenica was being controlled by Dutch peace-keepers as more than 500 Bosnian Serb Soldiers under the command of General Ratko Mladic were besieging the town. Dutch soldiers without any use of bullets gave up the control of town, where many women repeatedly raped and then loaded on to trucks with children never seen again; men put into hangars and slaughtered in soccer fields with only use of knifes; and some of those buried in mass graves. Thousands of Muslims in Srebrenica were massacred without any mercy in warehouses, soccer fields and terrains (Holbrooke, 1998:69). In fact, I spent long hours unsuccessfully trying to find a way to stop the tragey in Srebrenizca and Zepa. My recommendation- to use airpower against the Bosnian Serbs in other parts of the country, as 
well as Srebrenca- had been rejected by the Western European nations that had troops at risk in Bosnia, an by the Pentagon. On the July, the same day the Serbs began killing Muslims systematcally in the soccer stadium( Holbrooke, 1998: 70)

In 04 April 2006, the Ministy of Interior honored "Brave!" Dutch soldiers by Golden Medal with ceremony for their "eminent services" held in Srebrenica during Bosnian War. In April, 2007, one year later, International Court of Justice announced court's decision on the events in Bosnia. Events were defined clearly as genocide. However, Serbia's acquittal was also decided by Court, apart from Serbia provided ammunitions for Cetniks (Hacioğlu, 2008:205). The extent of massacres carried out within "safety areas" was larger at scale and scope because of belated military intervention and the lack of willingness of International Community to intervene into conflict. On the other hand, the lack of common decision, and available dissidences among EU members, and UNSEC members prevented to implement rapid reaction moves.

\subsection{Humanitarian Intervention: Implementation of Security}

As war devastated the social life within Bosnian territory, UNPROFOR was not able to sustain security in "safety areas". Meanwhile, the UN arms embargo on conflicting parties prevented only Bosnian Muslims' efforts to defend home security. In addition to the arms embargo, UNPROFOR commanders were unconcerned and far away from taking responsibility as seen in Srebrenica. As UNSEC and EU stood unconcerned and expected some gains from negotiating table only, US took the responsibility during President Clinton's administration. UNPROFOR had been so thoroughly humiliated by mid-December 1994 that President Clinton offered to send 25.000 American troops to extract peacekeeping from Bosnia ( Baffin, 1996: 107). Apart from debates were endless for taking responsibility, the Serbs were advancing and repeating performance in the mid of 1995 . The Serbs were murdering and raping. The last shelling of a marketplace in Sarajevo killing more than 35 people, sparked decision makers to functionalize operation of NATO. On 20 August 1995 NATO began Operation Deny Flight driving Serb artillery out of Sarajevo and sustained security. NATO air operations in the former Yugoslavia began long before the attacks of 30 August 1995. The first involvement was Operaton Maritime Monitor, on 16 July 1992, followed by Sky Monitor on October 1992. Deny Flight itself began 12 April 1995. 5 times offensive air operatons were authorized under the dual key UN/ NATo systems(Baffin, 1996: 114).

Not only the NATO's offensive air operations deterred the Serbs but also rejuvenated Bosnian Army. After US Congress voted to end arms embargo in favor the Bosnian Government; Bosnian Army rejuvenated and successfully managed a series of attacks in central Bosnia withdrawing the Serb irregulars. Alliance of Bosnian Muslims and Croats, Bosnian army's advancement into the Serbian occupied lands, magnitude of NATO's military operations led the Serbian Authorites to return negotiation table.

\section{5. 'Incomplete' Peace Agreement of the Dayton: Sustaining short term interethnic Peace and Security.}

On 21 November 1995, The Dayton Peace Accord was signed by the participant in the ceremony. Milosevic, Izetbogovic and Tudjman were on the same table again. Negotiaton process was managed by Richard Holbrooke who had been appointed before by the Clinton Administration as the senior field negotiator. The General Framework Agreement: (i) Defines Bosnia -Herzegovina $(\mathrm{BiH})$ as an Independent State, (ii)BiH consists of one Federation and a Republic; the Federation of Bosnia and Croatia; The Republica Srpsky, (iii) The Lands controlled by federation is 51 per cent; by RS is 49 per cent, (iv) One central government in Sarajevo, a national assembly, presidency and judiciary system will be in joint system, (v) President and members of Assembly will be elected under the condition of Democracy, (vi)Collective presidency system consists of Bosnian, Croatian and Serbian members on a rotation basis.

According to Agreement 60.000 NATO soldiers will be deployed to prevent future possible conflicts. Implementation Force is going to be responsible to implement peace and security. Later times, Implementation Forces converted into Stabilization Forces. According to Bieber, DPA have brought peace, but only limited success in fundamentally improving interethnic relations and establishing a functioning system of joint decision- making between the three predominant groups of the country ( Bieber; 2002: 1). Bieber also stresses that as the Croatians and the Serbs follow their antogonistic politicak moves within state, the interethnic peace might disintegrate. Problems with balancing 
competing demands of constituent states, opposition of the Serbs against Kosova's independence, Banja Luka's declaration as capital city of RS in 2009, power-sharing system, as being a multinational Federation, having dysfunctional entities, lack of efficiency of International Criminal Tribunals for the Former Yugoslavia( ICTY) at scale and scope, the premature activities of the International Community, and the lack of alternatives to Dayton will likely to disintegrate the Bosnian State, interethnic peace and security unless common economic interest between parties is to be maintained.

\section{Conclusion}

In the case of Bosnian War (1992-1995), The Peace Keeping Movements by International Participation have just maintained interethnic peace with slender success. The latest environment in Bosnia illustrates that interethnic peace sustained by the DPA is prone to disappear. Dissolving interethnic peace in the Balkans means the threat of mass killings and ethnic cleansing among rivals. As conflict in Bosnia examined, it is understood that the timing and scale of Peacekeeping strategies subsequently set up an environment in which ethnic cleansings turned into genocide. Peacekeping measures in the mid of conflict is far away from securing UN “safe areas". NATO's stong intervention and rejuvenation of Bosnian Army at the end of conflict urged the Serbian Authorities to return back to negotiation table mediated by R. Holbrooke. The DPA has established and stabilized the post conflict environment defining the new state structure with power sharing system. On the other hand Post Dayton Bosnian state in which recently conflicting parties are still debating on territorial issues, displaced persons, use of economic resources, and judgment of war fugitives. Hence, international community must contribute and facilitate initially peace progress by mediating unresolved issues and maintaining common interest among conflicting parties. Problems related to Post-Dayton Bosnian State can be isolated by maintaining common interest composing of both social and economic agendas. Agendas include sustaining improvement in health, education and culture, righteous judgment of fugitives, compensating war crimes, functionalizing open market principles, encouraging FDIs, mediating territorial disputes and sustaining transparency.

\section{References}

BAFFIN, JOHN: "The Destruction of Yugoslavia: A Teste for Killing”, (in) The World in Conflict War Annual 7 , Herndon, 1996 BIEBER, FLORIAN: "Bosnia- Herzegovina: Developments towards a More Integrated State", Journal of Muslim Minority Affairs, Vol 22, No.1, 2002

CAMPBELL, DAVID.: “Atrocity, Memory, Photography: Imaging the Concentration Camps of Bosnia- the Case of ITN versus Living Marxism, Part 2", Journal of Human Rights, Vol. 1, No. 2, 2002

CARMICHAEL, CATHIE: "Violence and ethnic Boundary maintenance in Bosnia in the 1990s", Journal of Genocide Research, Vol.8, No. 3, September, 2006

COLLIER, PAUL: ““Doing Well out of War”: Conference on Economic Agendas in Civil Wars”, London, Aptil, 1999.

COLLIER, PAUL: "Economic Causes of Civil Conflict and their Implications for Policy", Oxford University, 2006.

FIXDAL, MONA and SMITH, DAN: "Humanitarian Intervention and Just War" International Peace Research Institure, Oslo 1998

GRIFFITHS, STEPHAN I.: "Nationalism and Ethnic Conflict- Threats to European Security", Oxford Un. Press, New York, 1993.

HACIOĞLU, ÜMIT: “The Importance of Bosnia in Turkey’s Foreign Security”, MA Thesis- unpublished, Institute of Social Sciences, University of Beykent, İstanbul, 2005.

HACIOĞLU, ÜMIT: "The New Address of The Familiar Danger Bells: The Axis of Kosova- Bosnia", Journal of Strategic Studies, BUSAM, Vol:1 N:2 Autumn 2008

HACIOĞLU, ÜMIT: Tragedy in Bosnia: Documentary Film, 2008.

HAGEN, W.WILLIAM: “The Balkans in the Mid-Eighteenth Century”, (in) Foreign Affairs, V:78, N: 4, 1999

HOLBROOKE, RICHARD: To End A War, Random House, New York, 1998

HOROWITZ, DONALD: "Structure and Strategy in Ethnic Conflict", Annual World Bank Conference on Development Economics, Washington, April 20-21, 1998.

LIEBERMAN, BEN: "Nationalist Narratives, violence between neighbours and ethnic cleansing in BosniaHerzegovina: A case of Cognitive Dissonance”, Journal of Genocide Research, Vol.8, No. 3, September, 2006 
MALCOLM, NOEL: A Short History of Bosnia, New York, 1994

PATERSON, RICHARD Richard, James Gow, Alison Preston (eds), Bosnia by Television, British Film Institute, London 1996,

POLLACK, C. EVAN: "Intentions of Burial: Mourning, Politics, and Memorials Following the Massacre at Srebrenica", Death Studies, 27, Brunner Routlegde,

RAMET, SABRINA: Balkan Babel: The Disintegration of Yugoslavia from Death of Tito to Ethnic War, Westview, Boulder, 1996

TURKOVICH, BISERA: “ Bosnia and Herzegovina in the Changing World Order”, Sarajevo, Invest, 1996

VAYRYNEN, RAIMO: "Preventing Deadly Conflicts: failures in Iraq, Yugoslavia, and Kosova" (in) Confrence preceedings of 40th annual Convention, International Studies Association, Washington, 1999

YENIGÜN, C ve HACIOĞLU, Ü: “Bosnia and Herzegovina: Ethnic War- Incomplete Peace Agreement”, K. İnat et al., (in) Dünya Çatışma Bölgeleri, Nobel, İstanbul, 2004

YILMAZ, SAİT: National Security Report for Turkey, Beykent University, BUSAM, İstanbul, Ekim 2007.

Reports and internet

A Helsinki Watch Report: Human Rights Watch, 1992;1993

The World Bank REPORT, 2004: International Development Association, Country Assistance Strategy for Bosnia and Herzegovina Report No: 29 196-BA

The World Bank: An OED Evaluation of World Bank Support, BİH: Post-Conflict Reconstruction and the Transition to a Market Economy, Washington, 2004

www.setimes.com 